\title{
Pushing Boundaries
}

\section{Reforming the Digital Youth Agenda through Cultural Competence with Eliza T. Dresang}

\author{
Af Beth Joy Patin
}

\section{This article is written in memory of Eliza T. Dresang}

\begin{abstract}
Artiklen bestemmer kulturel kompetence som evnen til at kende og respektere egen og andres kulturer. I løbet af sin karriere arbejdede Dr. Eliza Dresang intenst for at gøre bibliotekernes service og materialer til børn mere inkluderende og mere reflekterende i relation til børns forskellige kulturer og fallesskaber. Selvom Dresang blev mest kendt for sin teori 'Radikal cendring' (1999), kampede hun for alle børns rettigheder på biblioteker. Denne artikel giver et signalement af Dresangs arbejde med multikulturel litteratur og kulturel kompetence. Den beskriver udviklingen af et bibliotekskursus baseret på viden om kulturel kompetence og den ender med at opsummere de foreløbige resultater fra to forskningsprojekter, der forsøger at demonstrere og empirisk underbygge betydningen af kulturel kompetence både for digitale unge og for de voksne, der arbejder sammen med dem.
\end{abstract}

Beth Joy Patin, MLIS, PhD Candidate, Lecturer, The Information School, University of Washington bethp@uw.edu
"[Children are] real people who have a right to the same community, interaction, and access that other community members have, as well as the right to the support they need to deal with these successfully". (Eliza T. Dresang, Radical Change, 74)

\section{Introduction}

Cultural competence refers to the ability to know and respect one's own culture and that of others. Throughout her career Dr. Eliza T. Dresang worked diligently to help make children's library services and materials more inclusive and reflective of those children's cultures and communities. Though probably most well-known for her theory Radical Change (1999), as early as 1977 Dresang was championing for the rights of all children in libraries. In the mid-1970s, Eliza T. Dresang was the director of the Instructional Materials Center at Lapham Elementary School in Madison, Wisconsin. Approximately one-third of the 350 students in the school were designated "handicapped" for various reasons, but the administration, teachers, and students pulled together to create what today would be called an inclusive environment. Dresang led the way by creating a model library curriculum that supported the entire student body. In a 1977 article for School Library Journal, fiercely titled "There Are No Other Children," Dresang argued that librarians must "look at every child, at every need" and develop their programs "from an understanding of the needs of the children." 
This focus on the needs of youth guided Dresang throughout her career. Through her professional work and research, she in turn guided all of us to a better understanding of the needs of the youth we want to serve, and she demonstrated how library services could evolve along with the changing needs of youth throughout the decades. At the center of each of her actions, there is a strong concern for the needs of youth and how adults can better meet these needs. This can be seen especially clearly in her advocacy for quality multicultural resources for youth and cultural competence in the adults who serve them.

The term culture can have many different meanings. For this paper, culture is defined as "the behaviors and beliefs, and characteristic of a particular social, ethnic, or age group" (dictionary.reference.com 2015). Specifically referring to the culture of contemporary digital culture young people from various ethnicities. According to LaFromboise et al, there are many different aspects of cultural competency. Furthermore, Lafromboise et al. propose five methods that individuals can achieve this cultural competency:

- through assimilation (becoming part of a second culture, one of which is considered dominant or more desirable)

- acculturation (knowing about but not participating in a second culture, one of which is considered dominant)

- alternation (knowing about two different cultures, neither of which is considered dominant, and altering behavior to fit a particular social context within either culture)

- multicultural model (maintaining distinct identities while individuals from one culture work with those of other cultures to serve common. . . needs, neither considered dominant)

- fusion (melting pot where former cultures blend indistinguishably).

These authors propose that the alternation model in which a person becomes comfortable in one's own culture as well as a second culture, is ideal. For the youth involved in this study, thinking in terms of easily moving back and forth between two cultures, not assuming one or the other is dominant, is useful in questioning whether the reading experience will begin to lead to an initial level of cultural competency in two or more distinctly different cultures. This is an issue that has never, to the best knowledge of the current researchers, been investigated, even on a more or less superficial or beginning basis.

This article serves as a reflection of Dresang's early work in multicultural literature and cultural competence, describes the creation of a course based on cultural competence foundations, and finally summarizes the preliminary results of two research projects seeking to help demonstrate the value of cultural competence for both digital youth and the adults who engage with them.

\section{Radical Change Theory}

Through her service as a member of the $1991 \mathrm{Cal}-$ decott Committee, Dresang was motivated to study what she noticed as a growing phenomenon: a shift in children's literature. Dresang termed this change as Radical Change. Dresang believed that books were shifting their formats and types to be more consistent with the types of media digital youth were interacting with like television and computers. These books tended to mimic hyperlinks, used non-linear formatting, and often introduced new and previously unexpressed voices.

Radical Change theory describes, explains, and predicts how digital youth interact with book in the digital age and how children's book publish has changed and continues to change (Mills et. al. 2015). Radical Change can be recognized in many different types of contemporary children's books through three classifications. Dresang identified three types of change that was occurring in children's literature: 1: changing forms and formats, 2: changing perspectives, and 3: changing boundaries. Changing forms and formats include: graphics in exciting new forms and formats, words and pictures reaching new levels of synergy, nonlinear organization and format, non-sequential organization and format, multiple layers of meaning, and finally, interactive format. Changing perspectives includes multiple perspectives, visual and verbal, previously unheard voices, and youth who speak for themselves. Changing Boundaries includes subject previously forbidden, settings previously overlooked, characters portrayed in new, complex ways, new types of communities, and unresolved endings. Connectivity refers to the connections that readers make with hypertext-like links, both visual and mental, prompted by the changing forms and formats of 
handheld books. This idea also includes introducing students to new perspectives and cultures. Interactivity refers the particular way digital youth interact with texts by making decisions as they read often in a non-linear way. Access refers to the breaking of long-standing barriers in literature for youth including certain topics, characters, and styles of language.

Radical Change is still relevant after over fifteen years. Research on digital-age youth is still needed and valued. Dresang's theory has been expanded by Kyungwon Koh to utilize the key concepts of Radical Change-interactivity, connectivity, and accessin a new typology to describe, explain, and predict youth information behavior (Mills et. al. 2015). Additionally, Pantaleo uses Dresang's theory to study how children read postmodern picture books. Even Dresang revisited Radical Change theory in 2008 and posited that handheld (print) children's books would eventually be replaced by some type of vastly improved e-reader, an indication that the predictive power of Radical Change theory is still relevant.

\section{Design and Creation of LIS 564: Multicultural Literature for Youth}

In the United States by the end of the 1980s, the term "multicultural literature" was commonly used to refer to various kinds of diversity in literary representations. In some instances, the term broadly encompassed race and ethnicity, gender, differing abilities, class, religion, and sexual orientation, while in others it was used more narrowly. For Dresang, it was important that this term be applied to groups that have historically lacked power and authority in society, and therefore lacked representation in children's resources as well. In 2009 Dresang worked with Beth Patin, one of her PhD students, to develop a course encouraging the identification of and deliberations about issues relevant to the development of crosscultural competence in relation to U.S. ethnic minorities through authentic resources for youth. To facilitate this, Dresang and Patin provided knowledge and skill development in location, selection, evaluation, and discussion of various genres and formats of multicultural resources as well as in strategies to use them with youth. Setting it apart from other courses offered in the LIS field, this course related crosscultural competence to meeting information needs of children and young adults through library and information collection development and services.

\section{Building Bridges for Cultural Competence: Transformation through Multicultural Literature for Youth}

Dresang's continued work in the area of cultural competence differs greatly from much of the work currently available in this field. A number of books have been written about contemporary and historical multicultural literature for youth, (East and Thomas 2007; Kruse and Horning 1991; Naidoo and Dahlen 2012; Sims 1992) and numerous others have focused on multicultural education and teaching strategies central to it (Banks 2007; Harris 1993). However, none of those books has encompassed a critical multicultural analysis of specific types of youth literature with the stated purpose of promoting cultural competence or proficiency. And none has accepted the value of inauthentic literature in developing cultural competency. While more than one author has used the metaphors of literature as mirror (reflecting one's own culture), windows (into another culture), and even doors (moving into a different culture), Dresang took these metaphors further with the incorporation of all of these terms into the image of building a bridge that encompasses and links cultures, leading to a transformative experience, cultural competency, and transformative action.

Recently, Dresang was asked to write a book in the Multicultural Education Series published by Teachers College Press about the principles her course focused on with respect to cultural competence and transformative action. This unfinished work, tentatively titled Building Bridges for Cultural Competence: Transformation through Multicultural Literature for Youth (Dresang and Patin forthcoming), focuses on the following: the growth of authentic multicultural literature in the United States; models for achieving or promoting cultural competency or proficiency; an in-depth critical multicultural analysis of specific genres of this literature; and how multicultural literature can be used by educators as a transformative vehicle for young people of all ages to move toward cultural competency with a strong potential for social action. Though many librarians and scholars would argue that reading changes and empowers us, for Dresang it was not enough to believe this; we have to know it. In order to investigate the transformative nature of reading, Dresang was engaged in two important research projects at the time of her passing. 


\section{Validating a Global Reading Challenge}

The first project was based on the firm belief that reading high quality, culturally specific literature can lead young readers to gain cultural competence. However, there is little systematic research upon which this assertion can be based. Inspired by Lepman's work (2002), scholars and professionals have expanded upon it, leading to the frequent statement that such high quality, culturally specific literature can serve as mirrors for children to see themselves, and windows to see and understand youth from cultures that differ from their own as well as doors that encourage them to enter and experience those other cultures for ultimate understanding. This research study, in the preliminary and early results stage, is designed to help fill this evidence gap with systematically gathered concrete evidence about the results of reading high quality, culturally specific globallyoriented literature for children 9 and 10 years of age. It focuses on a convenience sample of children from the 2500 in 45 schools who are participating in a Global Reading Challenge. It also seeks evidence of the impact of a shared reading experience for digital youth who are part of a world dominated by interactive social media.

Four research questions drove this research:

1. What, if any effect, does the close reading of high quality, culturally specific, globally-oriented youth literature across a diversity of experiences have on children's information about the cultures about which they read?

2. What, if any effect, does the close reading of high quality, culturally specific, globally-oriented youth literature across a diversity of experiences have on children's gaining active cultural competence in relation to the cultures about which they have read?

3. What, if any effect, does the close reading of high quality, culturally specific, globally-oriented youth literature across a diversity of experiences as part of an interactive team experience have on children's information about the cultures about which they read?

4. What, if any effect, does the close reading of high quality, culturally specific, globally-oriented youth literature across a diversity of experiences as part of an interactive team experience have on children's gaining active cultural competence in relation to the cultures about which they have read?

The researchers employed three models or theoretical frameworks to develop the data collection instruments and later to analyze the results of the data collected and to reach some answers to RQ1 and RQ2. The first of these is Critical Multicultural Theory, the application of which to children's literature is most thoroughly developed by Botelho and Rudman (2009). According to this theory, "children's literature is read against its sociopolitical context. Readers ascertain what cultural themes are imbedded in the work (5)." Children must read the ten books selected quite closely exposing them to sociopolitical context where it exists. The research will reveal whether the students understand the sociopolitical context. A second model the researchers employed is one that Deborah Abilock (2006) developed to measure where on a continuum her students are in achieving cultural competency. Her visual representation introduces the notion that students, teachers, and librarians can work to become more and more culturally competent along a scale that runs in six stages from Destructiveness to Cultural Proficiency. The third model the researchers employed is a more impact-oriented model addressing changes in curricular content, in this case book content that teachers can make to help students move toward becoming culturally competent. This model, by James Banks (2007), delineates four Levels of Integration of Ethnic Content to guide teachers who are striving to lead their students to cultural competency. The lowest level focuses on food, holidays, heroes and other discrete cultural elements while the final level presents the outcome of becoming culturally competent, i.e., students are involved in grappling with real social issues and in taking action to stop injustices. The final notes, if accepted, will give statistics for book content falling at each level.

The researchers are using an explanatory sequential mixed-methods design (Creswell, 2014) with a quantitative phase that informs a following-qualitative phase. The population consists of a sub-sample of the 4th and 5th grade students in 12 of the 45 schools participating in Global Reading Challenge Teams in the 2013 - 14 school year in Seattle. The schools were chosen to represent the variety of socioeconom- 
ic levels and reading scores achievements represented throughout the city. It is noteworthy that present among the ten finalists in the previous year, were both a school with the highest and another school with the lowest proportion of children on free and reduced lunch, a U.S. measure of poverty commonly used in schools.

Despite the fact that the previous evaluation of this project did not consider cultural impact or impact of diversity of experience, some youth volunteered this information anyway. One student wrote "Thank you Ms. Sherman for showing me that I can change racism. And stand up to the people that are racist." Many others mentioned being empowered to stand up to bullies. One of the classes involved in last year's study, read a book about the shortage of water in Sudan and became involved in the Sudan Water Project. The current survey instrument has been constructed, pretested, and administered to the students in the 12 participating Seattle Schools and was administered before the current year's reading list was distributed to students. As might be expected, young readers knew little about cultures other than their own at the beginning and had no plans for action. The results of this study will provide the first known research-based evidence about the impact on cultural competence of young people's close reading of high quality, culturally specific, globally-oriented youth literature across a diversity of experiences. Jella Lepman and many others have held firm to the belief that this type of reading can ultimately lead to cultural competency and world peace. This first step determines what information at least one group of young readers gain about other cultures through reading in a connected learning situation and how their attitudes and actions are affected by such reading.

\section{Measuring Impact of Cultural Competence In- struction}

\section{Introduction}

Culture refers to socially transmitted behavior, patterns, arts, and beliefs. Cultural competence is regarded as the ability to know and respect one's own culture and that of others; for many, acting upon this knowledge to effect change is an essential component of competence. This section of the paper introduces a preliminary study of the perception of graduate library students about how well a specific course helped prepare them to be cultural competent. An electronic survey was used to collect data and was constructed based on a survey by Hill and Kumasi (2011) as well as both closed- and openended questions constructed by the authors. Following previous research, a "gap-analysis technique was employed to determine discrepancies between students' prior knowledge and actual learning relative to cultural competence" (Hill and Kumasi, 2011 p.1). This study, after all phases, has the ability to investigate whether the course designed to increase cultural competence is having its desired impact. Additionally, this evidence can be used to support curriculum change in Library and Information Science field.

\section{Problem statement}

Often scholars and professionals have argued that high quality, culturally-specific instruction can lead professionals to gain cultural competence. However, there is little systematic research upon which this assertion can be based. Those who make such statements are as convinced that they are true, but when we, as scholars, are challenged to back these statements up with empirical evidence, we find that there is little or no systematic research upon which these assertions can be based. We just 'know' it is true. This research study, in the preliminary and early results stage, is designed to help fill this evidence gap with systematically gathered concrete evidence about the perception of library students on the impact of their cultural competence course.

\section{Research Questions}

The research questions driving this theory were:

1. How well do students enrolled in LIS 564/569 feel that course prepared them to become culturally competent practitioners?

2. Was the course transformative, i.e. did it encourage students take social action?

\section{Context Setting and Background}

As mentioned previously, during the autumn of 2009, Dresang and I worked together to create a course on multicultural literature that to our knowledge was different that previous iterations of the course in the LIS fields. We collected as many syllabi for multicultural literature courses for youth and courses that touched on the subject (for example, one unit in a regular youth literature course) and 
reviewed them for teachings strategies and concepts covered. We encountered several courses which primarily focused on negative examples of multicultural literature: what not to share with students and many more which focused on positive, authentic examples of literature.

We then went to work designing a course based on the principles of cultural competence and used both Abilock and Banks' (2007) theories to help us in formulating our curriculum. Our course used authentic multicultural literature to help our students move positively through the cultural competence continuum. The course introduced students to the psychology of racism, identity construction, and theories of cultural competence as a framework to help them understand how to engage with course materials. Resources in the course focused on different United States minority and ethnic groups and were selected to demonstrate authentic cultural resources and materials that would help transform students as they moved along the continuum.

\section{Theoretical and Conceptual Frameworks}

The researchers employed two models or theoretical frameworks to develop the data collection instruments and later to analyze the results of the data collected and to reach some answers to the research questions. The first of these models, we employed is one that Deborah Abilock developed to measure where on a continuum her students are in achieving cultural competency. Her visual representation introduces the notion that students, teachers, and librarians can work to become more and more culturally competent along a scale that runs in six stages from Destructiveness to Cultural Proficiency.

The second model the researchers employed is a more impact-oriented model addressing changes in curricular content, in this the students' perceptions in the courses' motivation toward becoming culturally competent. This model, by James Banks (2007), delineates four Levels of Integration of Ethnic Content to guide teachers who are striving to lead their students to cultural competency.

The lowest level focuses on food, holidays, heroes and other discrete cultural elements while the final level presents the outcome of becoming culturally competent, i.e., students are involved in grappling with real social issues and in taking action to stop injustices. One of the research aims was to discover if this type of course motivates students to work with communities other than their own and to understand if they engaged in the final stage of Banks's model, transformative social action and therefore demonstrating cultural competence.

\section{Methodology and Data Analysis}

The participants for this pilot study were library graduate alumni who had previously taken our course on cultural competence and multicultural literature. Participants volunteered to take part in the pilot and were conveniently recruited. Most participants (75\%) took the course in 2010 and had a significant amount of time to reflect on the course's impact.

The instrument was an electronic survey with twelve questions with both closed- and open-ended responses. The instrument designed to gauge whether the course led to transformative action and for respondents to rate their prior knowledge/experience with cultural competence items, their perceived knowledge/experience gained due to the course, and finally, the importance of each item to their librarianship goals.

To analyze the data, "the gap scores for the study were computed using a formula that calculated the difference between each respondent's ranking of their prior knowledge and the knowledge/experience gained resulting in what we have termed knowledge gaps" (Hill and Kumasi, 2011 p. 4). Hill and Kumasi explain this process:

"A knowledge gap is an indicator of the extent to which students perceive their coursework to have prepared them in such a way that they come away with more knowledge than they already had about a given aspect of cultural competence.

A knowledge gap is calculated by subtracting the prior knowledge score from the knowledge gained score on any given item for each respondent. A negative knowledge gap score indicates that students perceive that the amount of knowledge they've gained is below their prior knowledge on a given aspect of cultural competence. By contrast, a positive knowledge gap score indicates that students perceive that their LIS coursework resulted in them having either the same level or an in- 
creased amount of knowledge than they had upon entering the program" (Hill and Kumasi 2011, p.4).

For these questions, participants were instructed to rate their responses using a 7-point Likert scale, in which 1 indicates no or low prior or gained knowledge; 4 indicates moderate level of knowledge; and 7 indicated high level of prior or gained knowledge about a particular aspect of cultural competence. Knowledge gaps were calculated using the averages of each score reported for each item.

\section{Preliminary or Early Results}

Early results seemed to indicate a positive effect of the cultural competence course on both student's gained knowledge and experience as well as in the motivation of students to become socially active.

All respondents agreed on a 5 point Likert scale that the course was highly relevant to their practice of librarianship with several indicating that they believed the course should be mandatory. One participant responded, "This will always be The Class I look back on as having been the most influential class I took during my MLIS program. I think a form of LIS 564/569 should be required for all public librarians, in particular. I am grateful to have taken it, and honored to have been a part of such a growth-filled learning experience." Another participant mentions the value of the course with regards to her practice of librarianship but did not stop there, "I wish I could take it again! This class did influence my librarianship, but it also has given me a lot of skills that I use in my life."

Some of the valuable lessons from the course students mentioned were the need for diverse books and

\begin{tabular}{|l|c|c|c|c|}
\hline Cultural Competence Item & $\begin{array}{c}\text { Prior Knowledge } \\
\text { Avg }\end{array}$ & $\begin{array}{c}\text { Knowledge/Ex- } \\
\text { perience Gained } \\
\text { Avg. }\end{array}$ & $\begin{array}{c}\text { Knowledge Gaps } \\
\text { Avg. }\end{array}$ & $\begin{array}{c}\text { Importance of } \\
\text { Item Avg. }\end{array}$ \\
\hline $\begin{array}{l}\text { Understanding of the term "literacy" } \\
\text { including cognitive and sociocultural } \\
\text { perspectives. }\end{array}$ & 6.25 & 2.25 & 6.5 \\
\hline $\begin{array}{l}\text { Knowledge of the cultural differences } \\
\text { between ethnic populations in the U.S. }\end{array}$ & 4 & 5.75 & 1.75 & 6.5 \\
\hline $\begin{array}{l}\text { Familiarity with the history of library } \\
\text { service to individuals from various cul- } \\
\text { tures. }\end{array}$ & 3 & 5.25 & 2.25 & 5.5. \\
\hline $\begin{array}{l}\text { Recognition of how individuals from } \\
\text { various cultures access information. }\end{array}$ & 2.75 & 5.25 & 2.5 & 6 \\
\hline $\begin{array}{l}\text { Recognition of barriers to information } \\
\text { access and use that may exist for indi- } \\
\text { viduals from various cultures. }\end{array}$ & 2.75 & 5.75 & 3 & 6.5 \\
\hline $\begin{array}{l}\text { Collection development strategies that } \\
\text { reflect the information wants and needs } \\
\text { of individuals from various cultures. }\end{array}$ & 2.5 & 6 & & \\
\hline $\begin{array}{l}\text { Recognition of the role libraries play in } \\
\text { providing outreach and specialized ser- } \\
\text { vices to various cultural groups in the } \\
\text { United States. }\end{array}$ & 2.75 & 6.25 & 3.5 & 7 \\
\hline $\begin{array}{l}\text { Considering the impact that recruit- } \\
\text { ing library professionals from various } \\
\text { cultural backgrounds has on library } \\
\text { service. }\end{array}$ & 3.25 & 6.81 & 2.75 & 7 \\
\hline Overall Averages & & & & \\
\hline
\end{tabular}

Table 1. Knowledge Gap Respondent Scores. 
the use of multiple information resources to communicate cultural awareness, the ability to examine materials for their cultural accuracy (both text and illustration), and to discuss culture in an effective manner, and finally, to be knowledgeable about other communities and work with them in a compassionate way. All respondents agreed on a 5 point Likert scale that the course was highly motivating to work with communities different than their own. Each student gave examples of how the course had motivated them to work within their communities, but one story was especially powerful. The participant explains that this course "completely changed the focus of my approach to libraries and literacy." They went on to mention two projects they were currently involved in because the course including receiving two grants "that recognize the importance of validating cultural awareness and inclusion as a springboard to family literacy connections in the Hispanic community". Additionally, the student is working to design an after school program focusing on literacy skills for bilingual families supported by authentic multicultural picture books, graphic novels, and chapter books in both English and Spanish. The goal of this cultural connection program is to enable families to participate in literacy activities that will continue to be supported through community library use in rural areas and begins with Hispanic literature but will include other cultures over time, "connections will be made through the use of authentic literature, use of video and authentic experiences such as sharing the culture of food, games and other customs which reflect basic cultural awareness".

This area of the survey includes eight statements, building off of Hill and Kumasi (2011), where students rated according to their prior knowledge, the importance of learning the concept presented, and the knowledge they gained about the concept through this course. The knowledge gaps had a range of variance, but all items revealed a positive knowledge gain. For all 8 items, respondents indicated growth from 1.75 to 3.5 on each item, with an average of 2.89 for all items. Though the response might be different in a full scale study, our study did not result in any neutral or negative knowledge gaps. Neutral knowledge gaps would have indicated little or no knowledge or experienced was gained because of the course. A negative knowledge gap would indicate students understand more about the cultural competence items before the course and the course did not introduce any new knowledge or provide any new experiences for the students.

\section{Significance and Limitations of the Study}

The results of this study will provide research-based evidence about the impact of this cultural competence intervention on graduate school library students. Additionally, it will be a first step in demonstrating this type of course leads to transformative social action. Though only a pilot study and in its preliminary stages, the study yields exciting results. This study takes a small step in validating the tool and methods used by Hill and Kumasi (2011) and seems to validate the successfulness of our course as a positive intervention strategy to improve cultural competence skills. This study also points to the important skills that students took away from the course and demonstrates the course as a major motivating factor in their transformative social action.

This study is just a pilot study and in no way can the impact of this type of intervention be generalized to a wider audience. This study was just to test the usefulness of the tool designed by Hill and Kumasi (2011) and see if this instrument might accurately impact of the course and transformative social actions of the students.

\section{Conclusion}

Dresang and many others have held firm to the belief that these types of experiences can ultimately lead to cultural competency and world peace. Our course is working to radically change the way library professionals engage digital youth by helping them provide authentic multicultural materials from a variety of perspectives. Our research on the global reading challenge was the first step in helping to determine what information at least one group of young readers gain about other cultures through reading in a connected learning situation and how their attitudes and actions are affected by such reading. Finally, we are beginning to have evidence that course as an intervention positively effects those students who engage with the course materials. To the very end, Eliza T. Dresang held true to her belief that we should keep the needs of children, no matter what their backgrounds, at the very center of librarianship. 


\section{References}

Abilock, D (2008). Educating studend for crosscultural proficiency. In P. Montiel-Overall \& D. C. Adcock (Eds.), School library services in a multicultural society. Chicago, Ill.: American Association of School Librarians.

Agosto, D (2005). Information literacy: Essential skills for the information age. Journal of the American Society for Information Science and Technology: JASIST, 56(9), 1008.

Banks, JA (2007). Educating citizens in a multicultural society. New York: Teachers College Press.

Banks, JA (2009). Teaching Strategies for Ethnic Studies (8th ed.). Allyn \& Bacon.

Banks, JA (2012). Encyclopedia of diversity in education. Thousand Oaks, California: SAGE Publications, Inc. Retrieved fromhttp://site.ebrary.com/ $\mathrm{id} / 10582386$

Bishop, RS (1982). Shadow and substance: AfroAmerican experience in contemporary children's fiction. Urbana, Ill.: National Council of Teachers of English.

Botelho, MJ \& Rudman, MK (2009). Critical multicultural analysis of children's literature: mirrors, windows, and doors. New York: Routledge.

Creswell, JW (2014). Research design: qualitative, quantitative, and mixed methods approaches. Thousand Oaks, California: SAGE Publications.

Dresang, ET (1977). There are no other children. School Library Journal, 24(1).

Dresang, ET (1999). Radical change: books for youth in a digital age. New York: H.W. Wilson Co.

Dresang, ET (2006). Access: The Information-Seeking Behavior of Youth in the Digital Environment. Library Trends, 54(2), 178-196.

Dresang, ET (2008). Radical Change Revisited: Dynamic Digital Age Books for Youth.Contemporary Issues in Technology and Teacher Education, 8(3), 2008-09.
Dresang, ET \& Patin, BJ (Forthcoming). Building Bridges for Cultural Competence: Transformation through Multicultural Literature for Youth. New York: Teachers College Press.

Dresang, ET, Patin, BJ, \& Kotrla, B (2014). Cultivating Cultural Competence: Context, Culture, and Technology of a Global Reading Challenge. In iConference Proceedings. Berlin, Germany.

East, KA \& Thomas, RL (2007). Across Cultures: A Guide to Multicultural Literature for Children (annotated edition). Libraries Unlimited.

Harris, VJ (1990). African American Children's Literature: The First One Hundred Years. Journal of Negro Education, 59(4), 540-55.

Hill, RF \& Kumasi, K (2011). Bridging the Gaps: Measuring Cultural Competence among Future School Library and Youth Services Library Professionals. School Library Media Research,14.

Koh, K (2013). Theory-to-research-to-theory strategy: A research-based expansion of radical change theory.LIBINF Library and Information Science Research, 35(1), 33-40.

Kruse, GM, Horning, KT, University of Wisconsin-Madison, \& Cooperative Children's Book Center. (1991). Multicultural literature for children and young adults: a selected listing of books, 19801990, by and about people of color. Madison, Wis.: Cooperative Children's Book Center, University of Wisconsin-Madison, Wisconsin Dept. of Public Instruction.

Kumasi, K \& Hill, RF (2011). Are We There Yet? Results of a Gap Analysis to Measure LIS Students' Prior Knowledge and Actual Learning of Cultural Competence Concepts. Journal of Education for $\mathrm{Li}$ brary \& Information Science, 52(4).

LaFromboise T, Coleman, HL \& Gerton J (1993). Psychological impact of biculturalism: evidence and theory. Psychological Bulletin, 114(3), 395-412.

Lepman, J (2002). A bridge of children's books: the inspiring autobiography of a remarkable woman. Dublin: O'Brien. 
Montiel-Overall, P \& Adcock, DC (2008). School library services in a multicultural society. Chicago, Ill.: American Association of School Librarians.

Naidoo, JC \& Dahlen, SP (2013). Diversity in youth literature: opening doors through reading. Chicago: American Library Association.
Overall, PM (2009). Cultural Competence: A Conceptual Framework for Library and Information Science Professionals. Library Quarterly, 79(2), 175204. 